\title{
Synthesis, Characterization and Biological Activity of Mn(II)-Morin Complex
}

\author{
Shahabuddin Memon ${ }^{* 1}$ Qadeer Khan Panhwar ${ }^{2}$, Syeda Birjees Bukhari ${ }^{1}$, \\ Muhammad Iqbal Bhanger ${ }^{1}$ and Muhammad Qasim Samejo ${ }^{2}$ \\ ${ }^{1}$ National Center of Excellence in Analytical Chemistry, University of Sindh, Jamshoro-76080, Pakistan. \\ ${ }^{2}$ Dr. M. A. Kazi Institute of Chemistry, University of Sindh, Jamshoro-76080, Pakistan. \\ *Corresponding Author Email: shahabuddinmemon@yahoo.com \\ Received 22 June 2016, Revised 24 September 2016, Accepted 26 September 2016
}

\begin{abstract}
The article illustrates about the synthesis of Mn(II)-Morin complex in methanol solvent. The characterization of the complex was carried out using UV-visible, IR, ${ }^{1} \mathrm{H}$ NMR spectroscopic techniques and thermal (i.e. TGA, DSC) techniques. The complex formation was deduced by UVvisible spectra showing the successive Mn-Morin complex formation occurring at 1:1 (metal/ligand) ratio stoichiometrically. The antioxidant capacity of the complex has also been evaluated using 1,1-diphenyl-2-picrylhydrazyl (DPPH) free radical scavenging method. The work describes that flavonoids complexed with metal ions are more free radical scavengers than the free molecules.
\end{abstract}

Keywords: Metal, Flavonoid, Thermal, Antioxidant, Stoichiometry.

\section{Introduction}

A flavonoid is a polyphenolic compound present in all over the plant kingdom. Naturally, their basic structure shows the variety of substitution patterns on the two benzene rings (A and B) of 2-phenylbenzo- $\alpha$-pyrone nucleus [1]. Fig. 1 shows the basic flavonoid structure;<smiles>c1ccc(C2CCc3ccccc3O2)cc1</smiles>

Figure 1. Generic structure of flavonoids

Flavonoids perform variety of important functions in plants including UV screening, pigmentation, chemical defense against predators, iron uptake, and signaling pathways leading to $\mathrm{N}_{2}$ fixation, etc. Besides, they have attracted the interest of researchers from last two decades because of their organoleptic properties in foods (color and flavor). They also have important nutritional value and avert the evolution of various degenerative diseases for example cancer, cardiovascular diseases, and age related disorders. Additionally, flavonoids can also be applied for treating different other diseases such as diabetes mellitus, allergy, viral infection, inflammation etc. These effects are mostly associated with anticancer, enzymatic inhibition, antioxidant activity as well as interfering to free radical formation reactions [2].

Flavonoids being greatly explored secondary metabolites possess higher value of therapeutic actions. The chelating ability of flavonoids to metal ions results in the emergence of these molecules as new category having bioactivities with broad spectrum. Recently many strenuous efforts are undertaken to synthesize and characterize the novel type of metal flavonoid complexes due to their potential role in different fields. Rutin, morin, quercetin and other types of flavonoids forming transition metal complexes that 
may appreciably change the chemical properties of their analogous parent molecules [3-6].

It is confirmed in numerous studies that flavonoids function as antioxidants mainly by chelating metal ions [7]. Because of certain properties of metal flavonoid complexes such as synergic effect of metal ions and flavonoids, access to target spots as well as strong binding forces produced from the change in complex structure may contribute to many biological activities for instance, anti-tumor, antivirus, antibiosis, anti-free radical and anti-inflammatory [8]. Thus biological importance of such complexes is needed to be completely explored in future [9].

Morin (3,5,7',2', 4'-pentahydroxyflavone) is a member of flavonol class of flavonoids that is widely present in nature. It is also well known as good chelating agent, complexant as well as good antioxidant, due to these properties it has attracted many researchers [10]. The structure of morin is shown in Fig. 2. In complexation, it can use multiple chelation sites as shown in Fig. 3.<smiles>COc1cc(O)cc(O)c1C(=O)C(O)=C(O)c1ccc(O)cc1O</smiles>

Figure 2. Molecular structure of morin.

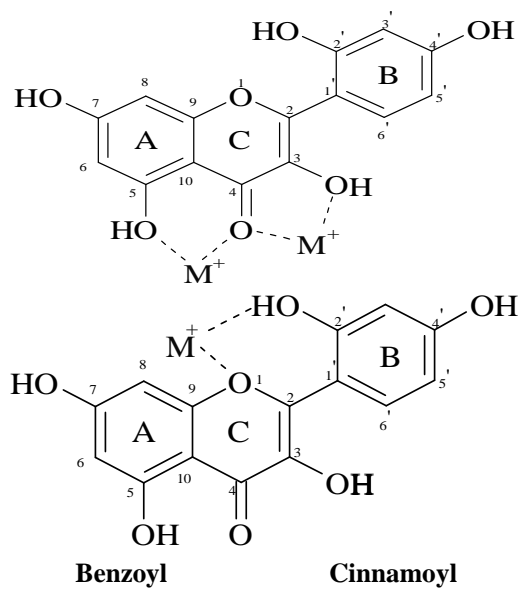

Figure 3. Different chelating sites in morin are available around carbonyl oxygen and ether oxygen
Metal ions are involved in large number of biological processes. As therapeutic agents, usage of metal ions increases the drug action as well as coordination of metal ions to drug molecules also raise the drug efficacy [11,12]. The role of metal complexes has been recognized from centuries in antimicrobial activities and most fundamental breakthroughs are also known by them in medical history [13].

Manganese (Mn) and its compounds find historical importance in medicine [14]. $\mathrm{Mn}$ is an essential trace element for all forms of life [15] and considered to be the $12^{\text {th }}$ most abundant element in the biosphere. It is broadly available in biological materials, water, soil, and sediment [16]. It is an important metal for human health, being absolutely necessary for skeletal system development, metabolism, enzyme activation, reproductive hormone function, immunological system function, antioxidant system $[17,18]$ and the nervous system function. It is also important in regulating cellular energy, blood clotting, bone and connective tissue growth $[19,20]$. Nevertheless, chronic excessive exposure or intake in man causes to distress the central nervous system exhibiting Parkinson's disease like symptoms. For this reason, $\mathrm{Mn}$ is considered to be the significantly toxic heavy metal. It can also affect the ecosystem negatively, accumulating in the food chain. When Fe and Mn are present in excess in drinking water, they cause the unpleasant taste and odor in drinks and foods, yellowish water appearance, staining of kitchen utensils, clothes and bath accessories. Both the metals are also involved in hardness of water that results in the failure of pressure in pumps, water pipes and heaters. It is also of special importance to determine $\mathrm{Mn}$ in trace amounts from huge number of environmental samples as well as various types of other matrices such as food, soil, stream sediments over and above air borne particulates [16].

$\mathrm{Mn}$ is also important in photosynthetic oxygen evolution in chloroplasts of plants. For this reason, most broad-spectrum plant fertilizers contain $\mathrm{Mn}$. In the human brain, $\mathrm{Mn}$ is bound to Mn metalloproteins, most notably in glutamine synthetase [21]. It is also an important cofactor for a variety of enzymes, including the antioxidant 
enzyme superoxide dismutase as well as enzymes involved in neurotransmitter synthesis and metabolism [22], others being hydrolases, lyases, isomerases etc [23]. About $12 \mathrm{mg}$ of $\mathrm{Mn}$ is contained by human body that is stored in tissues, bones, kidneys and liver [17]. For general population, diet is an important Mn source; about 2-9 $\mathrm{mg} /$ day of $\mathrm{Mn}$ is obtained from average food intake, while 1-20 mg Mn/tablet is supplemented by minerals and vitamins. For various age groups, the estimated safe and adequate daily dietary intake (ESADDI) levels are different, for example, for adults and adolescents, it is $2-5 \mathrm{mg} /$ day, while it is $0.3-2 \mathrm{mg} /$ day for infants and children up to 10 years age [24]. The consequences of Mn deficiency include altered carbohydrate metabolism, reduced glucose metabolism, abnormal lipid metabolism, and impaired insulin synthesis and action. Only a few instances of $\mathrm{Mn}$ deficiencies have been reported in humans, with symptoms including dermatitis, slow growth of hair and nails, decreased serum cholesterol levels, and decreased levels of clotting proteins. In addition, several diseases have been reported to be characterized by low blood Mn concentrations, including epilepsy, mseleni disease, down's syndrome, osteoporosis, and perthest disease [25].

The synthesis and characterization of $\mathrm{Mn}$ (II) complexes of different ligands is of growing interest in coordination chemistry [15]. The problem of antibiotic resistance has now reached a crisis and there is a need to double the efforts towards the design of new drugs. A number of reports show the use of Mn complexes as both antibacterial and antifungal agents [26]. In addition, flavonoids and their metal complexes also has become popular target of biological, biochemical and analytical studies [1]. So, in current study, the strategy is made to design the complex of $\mathrm{Mn}$ (II) with one of the flavonoids (i.e. morin) to get synergic effect from both the flavonoids and metallic ions.

\section{Material and methods \\ Reagents and instrumentation}

Solvents and reagents of analytically pure grade were used as received. HPLC grade methanol (MeOH) was obtained from Fisher Scientific UK Ltd. Morin. $2 \mathrm{H}_{2} \mathrm{O}$ was purchased from Sigma. Sodium methoxide (MeONa) was prepared by adding freshly cut small pieces of $\mathrm{Na}$ $(2.5 \mathrm{~g})$ to analytical grade dry $\mathrm{MeOH}\left(100 \mathrm{~cm}^{3}\right)$ and refractionated. $\quad \mathrm{MnCl}_{2} \cdot 4 \mathrm{H}_{2} \mathrm{O}$ salt was obtained from Sigma-Aldrich Co. DPPH and $\mathrm{KBr}$ were attained from Aldrich Chemical Co. All the measurements were done with an accuracy of $\pm 0.0001 \mathrm{~g}$.

UV-visible spectra of morin and [Mn(Morin) $\left.\left(\mathrm{H}_{2} \mathrm{O}\right)_{2}\right] \mathrm{Cl}_{3} 3 \mathrm{H}_{2} \mathrm{O}$ metal complex were recorded on double beam spectrophotometer (Perkin Elmer Lambda 35) in $\mathrm{MeOH}$ using 1.00 $\mathrm{cm}$ standard quartz cells. The IR spectra were obtained on FTIR spectrophotometer (Nicolet 5700) within 400-4000 $\mathrm{cm}^{-1}$ spectral range, using $\mathrm{KBr}$ pellets. ${ }^{1} \mathrm{H}$ NMR spectra were obtained on spectrometer (Bruker $400 \mathrm{MHz}$ ) in DMSO. Thermogravimetric analysis (TG) measurement was done in the temperature range $25-800{ }^{\circ} \mathrm{C}$ under $\mathrm{N}_{2}$ atmosphere at the heating rate $10{ }^{\circ} \mathrm{C}$ $\min ^{-1}$ (Thermal analyzer DT-30 Shimadzu). DSC curve was recorded in $\mathrm{Al}$ crucible under the conditions of $20{ }^{\circ} \mathrm{C} \mathrm{min}^{-1}$ heating rate, $20 \mathrm{mg}$ mass and $\mathrm{He}$ atmosphere (using $\mathrm{DSC}_{22} 2^{\mathrm{e}}$ Mettler Toledo).

\section{Job's method of continuous variation}

The stoichiometric ratio for the complex was determined by Job's method [27]. Solutions of equimolar concentrations $\left(4 \times 10^{-4} \mathrm{M}\right)$ were prepared in $\mathrm{MeOH}$. Both the components were mixed in 1:9 to 9:1. The maximum absorbance was noted at $420 \mathrm{~nm}$ from absorption plots.

\section{Synthesis of the complex}

The complex compound was prepared by simple route. The methanolic solution $(20 \mathrm{~mL})$ of Morin. $2 \mathrm{H}_{2} \mathrm{O}(0.30 \mathrm{~g}, 0.01 \mathrm{M})$ was prepared in a round bottom flask $(50 \mathrm{~mL}$ capacity) that produced brownish color. The salt of $\mathrm{MnCl}_{2} \cdot 4 \mathrm{H}_{2} \mathrm{O}(0.19 \mathrm{~g}$, $0.01 \mathrm{M})$ was added to the solution which subsequently changed the color of solution. After $1.5 \mathrm{~h}$ stirring time, the complex mixture was filtered through gravity filtration method and evaporated the filtrate slowly at room temperature. The dark brownish yellow product of $\mathrm{Mn}(\mathrm{II})$ Morin complex was obtained [28]. Washed the product with $t$-butanol, dried it in vaccum 
desiccator, while the yield was calculated as $73 \%$. Elemental analysis was found $(\%) \mathrm{C}, 37.15 ; \mathrm{H}$, 3.26, Anal. Calcd for $\left[\mathrm{Mn}(\right.$ Morin $\left.)\left(\mathrm{H}_{2} \mathrm{O}\right)_{2}\right] \mathrm{Cl} .3 \mathrm{H}_{2} \mathrm{O}$, $\left[\begin{array}{lllll}\mathrm{C}_{15} & \mathrm{H}_{19} & \mathrm{O}_{12} & \mathrm{Cl} & \mathrm{Mn}\end{array}\right]\left[M=481.385 \mathrm{gmol}^{-1}\right]: \mathrm{C}$, $37.39 ; \mathrm{H}, 3.98 \%$.

\section{Antioxidant activity}

Using previously reported method [29], the antioxidant activity/free radical scavenging activity of the $\mathrm{Mn}(\mathrm{II})$ complex was examined by DPPH stable free radical. The methanolic solution of about $0.1 \mathrm{~mL}$ morin standards of various concentrations was added to fresh DPPH solution of $57.65 \mu \mathrm{mol}$. The DPPH was reduced at $515 \mathrm{~nm}$ showing continuous decrease in its absorbance until the plateau was achieved for the reaction. At the time of measurement, the DPPH decomposition was determined with its blank solution for screening. Using calibration curve, starting DPPH concentration $\left(X_{\mathrm{DPPH}}\right)$ was obtained in the reaction medium with Equation 1 obtained by linear regression, while Equation 2 was used to convert the absorbance decrease into \%age. Abs., $\mathrm{T}=0, \mathrm{~T}$ only, denote the absorbance, zero time, and any specified time for absorbance, respectively;

$\mathrm{A}_{517}=0.009 \times 10^{-6} \times X_{\mathrm{DPPH}^{-}}-0.586, \mathrm{r}^{2}=0.9992$

$\% \mathrm{DPPH}$ remaining $\left.=\left([\mathrm{Abs}]_{\mathrm{T}=0}-[\mathrm{Abs}]_{\mathrm{T}}\right) \times 100 /[\mathrm{Abs}]_{\mathrm{T}=0}\right)$

\section{Antimicrobial activity}

In vitro antibacterial activity of different concentrations of morin and $\mathrm{Mn}$ (II)-Morin complex against locally isolated Gram positive (G $+\mathrm{ve}$ ) staphylococcus aureus (S. aureus) and Gram negative $(\mathrm{G}-\mathrm{ve})$ proteus vulgaris $(P$. vulgaris) was explored by disk diffusion method.

The solutions of the morin and the corresponding complex were prepared by dissolving them in DMSO to get $0.05 \%, 0.1 \%$, $0.15 \%, 0.2 \%, 0.25 \%$, and $0.3 \%$ solutions. Disks of $6 \mathrm{~mm}$ diameter (filter paper Whatmann No. 6) were impregnated with solutions $(20 \mu \mathrm{L})$ of both the compounds. They were dried at $30{ }^{\circ} \mathrm{C}$ for 2 min. in an oven. The disks were placed on the petri dishes with nutrient agar containing cultures of bacteria in lawn fashion [28].
The standards of antibiotic disks were used. Ciprofloxacin $(5 \mu \mathrm{g})$ and streptomycin were used for $P$. vulgaris and $S$. aureus, respectively. Lastly, the compounds were incubated for $24 \mathrm{hrs}$ at $37{ }^{\circ} \mathrm{C}$. For each compound, the experiment was done in duplicate. The inhibition zones were measured in $\mathrm{mm}$ for the disk of each concentration.

\section{Results and Discussion Synthesis and characterization}

The stoichiometric composition of the complex was validated with Job's plot. Band I of morin at $357 \mathrm{~nm}$ decreased and the complex band appeared at $420 \mathrm{~nm}$ as soon as the $\mathrm{MnCl}_{2} \cdot 4 \mathrm{H}_{2} \mathrm{O}$ salt was added to the ligand solution. The mole fraction $(X)$ of morin shows $X_{\mathrm{L}}=0.5$ value (Fig. 4) at maximum absorbance in plot of absorbance $v s$. mole fraction. It confirms the 1:1 stoichiometry of the complex formation between $\mathrm{Mn}$ (II) and morin (Table 1).

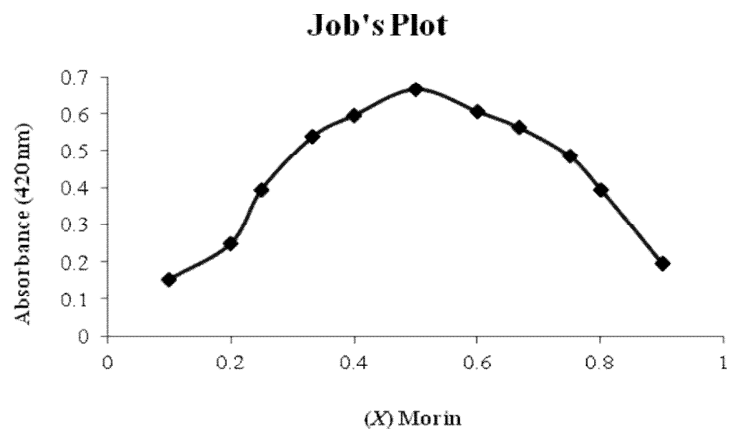

Figure 4. Job's plot showing 0.5 mole fraction value $(X)$ for the formation of Mn-Morin complex

Table 1. Metal and ligand showing preferred stoichiometric ratio and specific $p H$ value for maximum complexation.

\begin{tabular}{lccc}
\hline Flavonoid & Metal ion & $\begin{array}{l}\text { Flavonoid- } \\
\text { metal ratio }\end{array}$ & $\boldsymbol{p H}$ \\
\hline Morin & $\mathrm{Mn}(\mathrm{II})$ & $1: 1$ & 5.6 \\
\hline
\end{tabular}

\section{Physical properties of the complex}

The stable yellowish brown complex product is soluble in solvents such as EtOH, $\mathrm{MeOH}, \mathrm{DMF}$ and DMSO, moderately soluble in $\mathrm{CHCl}_{3}$ and $\mathrm{Me}_{2} \mathrm{CO}$, where as completely insoluble in $\mathrm{CCl}_{4}$ and water. Furthermore, the physicochemical properties of the complex are given in Table 2 . 
Table 2. Physico-chemical properties of Morin-Mn(II) complex.

\begin{tabular}{|c|c|c|c|c|c|}
\hline \multirow[b]{2}{*}{ Complex } & \multirow[b]{2}{*}{$\%$ Yield } & \multirow[b]{2}{*}{ Color } & \multicolumn{2}{|r|}{ СH\% } & Metal\% \\
\hline & & & $\begin{array}{l}\text { C Calculated } \\
\text { (found) }\end{array}$ & H Calculated (found) & Mn(II) Calculated (found) \\
\hline $\begin{array}{l}{[\mathrm{Mn}(\text { Morin) }} \\
\left.\left(\mathrm{H}_{2} \mathrm{O}\right)_{2}\right] \mathrm{Cl} .3 \mathrm{H}_{2} \mathrm{O}\end{array}$ & 73 & Brownish yellow & $37.39(37.15)$ & $3.98(3.26)$ & $11.41(11.01)$ \\
\hline
\end{tabular}

\section{$U V$-visible spectroscopic study of the complex}

The UV-visible spectra demonstrated in Figs. 5 and 6 are obtained in methanol for pure morin and its $\mathrm{Mn}$ (II) complex. Two bands are visible in the morin spectrum similar to most of the other flavonols and flavones. Band I at $357 \mathrm{~nm}$ shows the B ring absorption (cinnamoyl system), while Band II at $262 \mathrm{~nm}$ reveals the A ring absorption (Benzoyl system) (Table 3).

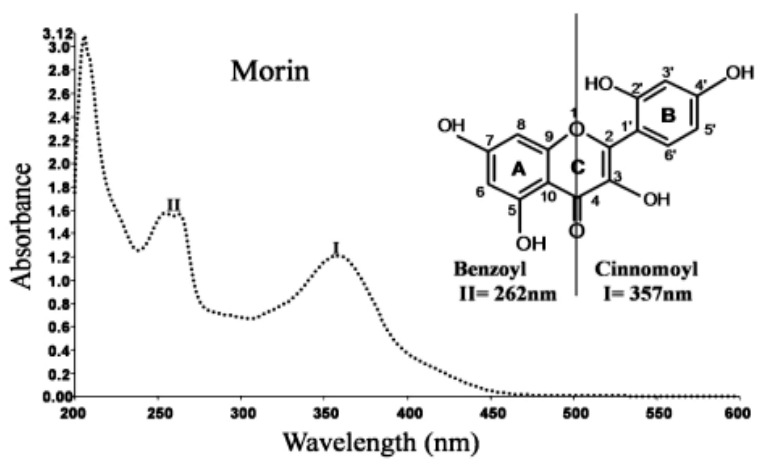

Figure 5. UV-visible spectrum of pure morin

These bands are appeared due to intraligand (IL) $n-\pi^{*} / \pi-\pi^{*}$ transitions taking place in the aromatic rings of the morin. On the other hand, complex spectrum relatively shows the shift in bands towards longer wavelength (Fig. 6). This shift is caused by the complexation that extends the conjugation. Thus, characteristic peak at $420 \mathrm{~nm}$ (isobestic point) is indicative of complex formation.

Table 3. Important characteristic bands for morin, deprotonated morin as well as its $\mathrm{Mn}$ (II) complex.

\begin{tabular}{l|l|l}
\hline Compound & $\lambda_{\mathbf{1}}\left(\mathbf{n}-\boldsymbol{\pi}^{*}\right)$ & $\boldsymbol{\lambda}_{\mathbf{2}}\left(\boldsymbol{\pi}-\boldsymbol{\pi}^{*}\right)$ \\
\hline Morin & $357 \mathrm{~nm}$ & $262 \mathrm{~nm}$ \\
Deprotonated Morin & $400 \mathrm{~nm}$ & $274 \mathrm{~nm}$ \\
{$\left[\mathrm{Mn}(\right.$ Morin $\left.)\left(\mathrm{H}_{2} \mathrm{O}\right)_{2}\right] \mathrm{Cl}_{2} 3 \mathrm{H}_{2} \mathrm{O}$} & $420 \mathrm{~nm}$ & $267 \mathrm{~nm}$ \\
& & \\
\hline
\end{tabular}

The most important information regarding the coordination site in morin can be easily observed from UV-visible spectra, which show that 1:1 interaction in metal:morin causes the bathochromic shift in both bands. Nevertheless, among all, 3-OH group is known to have most acidic proton that is the first site for complexation in conjunction with 4-oxo group [30].

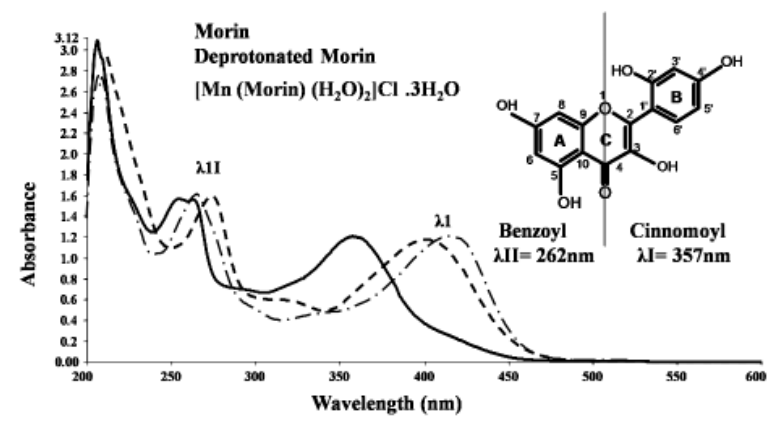

Figure 6. Relative UV-visible spectra of morin, deprotonated morin, and Mn(II)-Morin complex

\section{${ }^{1} \mathrm{H} N M R$}

${ }^{1} \mathrm{H}$ NMR data for morin and its corresponding complex are provided below individually for ligand molecule and complex compound.

Morin: $\delta 1260$ (s, 1H, 5-OH), 10.65 (s, 1H, 7-OH), 9.75 (s, 1H, 3-OH), 9.75 (s, 1H, 2'-OH), $9.39\left(\mathrm{~s}, 1 \mathrm{H}, 4^{\prime}-\mathrm{OH}\right), 7.08\left(\mathrm{~d}, J_{\mathrm{H}^{\prime} / \mathrm{H} 6^{\prime}}=1.8 \mathrm{~Hz}, 1 \mathrm{H}\right.$, $\left.2^{\prime}-\mathrm{H}\right), 6.31\left(\mathrm{dd}, 1 \mathrm{H}, 66^{\prime}-\mathrm{H}\right), 6.22\left(\mathrm{~d}, J_{\mathrm{H} 5 / \mathrm{H} 6}=8.5 \mathrm{~Hz}\right.$, $1 \mathrm{H}, 5 '-\mathrm{H}), 6.14\left(\mathrm{~d}, J_{\mathrm{H} 8 / \mathrm{H} 6}, 1.5 \mathrm{~Hz}, 1 \mathrm{H}, 8-\mathrm{H}\right), 6.05$ (d, $1 \mathrm{H}, 6-\mathrm{H})$.

Mn-Morin complex ([Mn(Morin) $\left.\left(\mathrm{H}_{2} \mathrm{O}\right)_{2}\right]$ $\mathrm{Cl} .3 \mathrm{H}_{2} \mathrm{O}$ ): $\delta 1339$ (s, $\left.1 \mathrm{H}, 5-\mathrm{OH}\right), 10.65$ (s, $1 \mathrm{H}, 7-$ $\mathrm{OH}), 9.67$ (s, 1H, 2'-OH), 9.45 (s, 1H, 4'-OH), 9.43 $\left(\mathrm{d}, J_{\mathrm{H} 2^{\prime} / \mathrm{H} 6^{\prime}}=1.8 \mathrm{~Hz}, 1 \mathrm{H}, 2^{\prime}-\mathrm{H}\right), 6.41\left(\mathrm{dd}, 1 \mathrm{H}, 6^{\prime}-\mathrm{H}\right)$, $6.32\left(\mathrm{~d}, J_{\mathrm{H} 5 / \mathrm{H} 6}=8.5 \mathrm{~Hz}, 1 \mathrm{H}, 5^{\prime}-\mathrm{H}\right), 6.23\left(\mathrm{~d}, J_{\mathrm{H} 8 / \mathrm{H} 6}\right.$, $1.5 \mathrm{~Hz}, 1 \mathrm{H}, 8-\mathrm{H}), 6.17(\mathrm{~d}, 1 \mathrm{H}, 6-\mathrm{H})$. 
${ }^{1} \mathrm{H}$ NMR data (Table 4) indicate that $\delta$ values of $\mathrm{Mn}(\mathrm{II})$-Morin complex were shifted to lower field relative to pure morin. This shift is correlated to increased conjugation obtained in the result of coordination. It is also the result of complex formation that causes the increased planarity of the ligand molecule. Hence, it can be demonstrated that the coordination of the metal ion occurred through the removal of phenolic hydrogen of 3-OH. It can also be revealed from data, which shows the absence of this proton. Thus, ${ }^{1} \mathrm{H}$ NMR and IR studies jointly demonstrate that 3-OH and 4-CO groups of morin are involved in complex formation [31].

Table 4. Assignments of ${ }^{1} \mathrm{H}$ NMR signals for morin and $\mathrm{Mn}$ (II)Morin complex.

\begin{tabular}{lllcc}
\hline S.No. & $\begin{array}{l}\text { Morin } \\
\text { ppm }\end{array}$ & $\begin{array}{l}\text { Mn-Morin } \\
\text { ppm }\end{array}$ & $\begin{array}{l}\text { Type of } \\
\text { proton }\end{array}$ & Position \\
\hline 1 & 12.60 & 13.39 & $\mathrm{~S}, 1 \mathrm{H}$ & $5-\mathrm{OH}$ \\
2 & 10.65 & 11.52 & $\mathrm{~S}, 1 \mathrm{H}$ & $7-\mathrm{OH}$ \\
3 & 9.75 & --- & $\mathrm{S}, 1 \mathrm{H}$ & $3-\mathrm{OH}$ \\
4 & 9.75 & 9.67 & $\mathrm{~B}, \mathrm{H}_{2} / \mathrm{H}_{4}, 1 \mathrm{H}$ & $2^{\prime}-\mathrm{OH}$ \\
5 & 9.39 & 9.45 & $\mathrm{~B}, \mathrm{H}_{2} / \mathrm{H}_{4}, 1 \mathrm{H}$ & $4^{\prime}-\mathrm{OH}$ \\
6 & 7.08 & 7.43 & $\mathrm{~S}, 1 \mathrm{H}$ & 6 '-H \\
7 & 6.31 & 6.41 & $\mathrm{~S}, 1 \mathrm{H}$ & $5^{\prime}-\mathrm{H}$ \\
8 & 6.22 & 6.32 & $\mathrm{~S}, 1 \mathrm{H}$ & $8-\mathrm{H}$ \\
9 & 6.14 & 6.23 & $\mathrm{~S}, 1 \mathrm{H}$ & $3^{\prime}-\mathrm{H}$ \\
10 & 6.05 & 6.17 & $\mathrm{~S}, 1 \mathrm{H}$ & $6-\mathrm{H}$ \\
\hline
\end{tabular}

\section{FT-IR}

Table 5 shows the FT-IR spectral data for morin and $\mathrm{Mn}$ (II)-Morin complex. The evidence of coordination between the metal ion and ligand molecule is also well illustrated by spectra provided in Fig. 7. The main features of the spectra are described below;

(1) Morin shows the characteristic frequency mode for $v(\mathrm{C}=\mathrm{O})$ at $1662 \mathrm{~cm}^{-1}$, but complex formation by $\mathrm{Mn}$ (II) may shift the peak towards $1649 \mathrm{~cm}^{-1}$ as illustrated by complex spectrum. It indicates that $\operatorname{Mn}(\mathrm{II})$ is coordinated to morin through a carbonyl oxygen and 3-OH/5-OH groups. In addition, the appearance of two peaks giving rise the coupling vibrations may be due to increased bond order of $\mathrm{C}_{4}=\mathrm{O}_{2}$ along with $\mathrm{C}_{3}-\mathrm{O}_{3}$ giving peaks at 1510 and $1446 \mathrm{~cm}^{-1}$ for the antisymmetric as well as symmetric stretching vibration modes for each $\mathrm{C}-\mathrm{O}$ group at both the chelating sites.

(2) There is slight shift in the frequencies of morin at 1258 and $1508 \mathrm{~cm}^{-1}$ for the peaks related to $v(\mathrm{C}-\mathrm{O}-\mathrm{C})$ and ring $v(\mathrm{C}=\mathrm{C})$ indicating no ring oxygen involvement in chelation.

(3) In complex spectrum, there is a peak at 536 $\mathrm{cm}^{-1}$ due to formation of $v(\mathrm{Mn}-\mathrm{O})$ that indicated the metal chelate formation, but no such band is present in the spectrum of morin.

An important and broad band appearing between the 3500 and $3000 \mathrm{~cm}^{-1}$ frequencies is assigned to $v(-\mathrm{OH})$ of water. In addition, the thermal analysis also supports the presence of coordinated water molecules [32].

Table 5. Assignments of the main IR bands for morin and MorinMn(II) complex.

\begin{tabular}{lcc}
\hline Morin cm $^{-1}$ & Mn(II)-Morin $\mathbf{~ m}^{-1}$ & Assignment \\
\hline$(3378-3153) \mathrm{b}$ & $(3389) \mathrm{b}$ & $v(\mathrm{O}-\mathrm{H})$ \\
$(1662) \mathrm{w}$ & $(1649) \mathrm{sh}$ & $v(\mathrm{C}=\mathrm{O})$ \\
$(1612) \mathrm{sh}$ & $(1607) \mathrm{s}$ & $v$ ring $(\mathrm{A}$ and B) \\
$(1508) \mathrm{s}$ & $(1510) \mathrm{m}$ & Ring B $(\mathrm{C}=\mathrm{C})$ \\
$(1458) \mathrm{sh}$ & $(1446) \mathrm{m}$ & $v$ ring C, $v$ C3-O3 \\
$(1258) \mathrm{vs}$ & $(1236) \mathrm{m}$ & $v(\mathrm{C}-\mathrm{O}-\mathrm{C})$ \\
$(1174) \mathrm{s}$ & $(1152) \mathrm{sh}$ & $\mathrm{C}=\mathrm{O}, \mathrm{C}=\mathrm{CH}$ \\
$(1144) \mathrm{m}$ & $(1148) \mathrm{m}$ & $(\mathrm{CH} 2)$ \\
& $(1094) \mathrm{s}$ & $v(-\mathrm{C}-\mathrm{O}-\mathrm{H})$ \\
& $(536) \mathrm{m}$ & $\mathrm{M}-\mathrm{O}, \mathrm{M}-\mathrm{O}=\mathrm{C}$ \\
& $(415) \mathrm{sh}$ & $\mathrm{M}-\mathrm{O}$ \\
\hline
\end{tabular}

b, m, sh, s and w stand for broad, medium, sharp, short and wide, respectively

\section{Thermal study of the complex}

Thermal methods were used for analyzing and investigating the metal complexes as well as their structures. Many physical and chemical transformations occur on heating the materials in conjunction with libration or absorption of heat. In such reactions, change in weight occurs which is subsequently measured by thermogravimetric analysis (TG). For understanding complex formation mechanism as well as complex stability, it is interesting to note the intermediate products produced on heating to investigate the complex. 
It is observed that $\mathrm{Mn}$ (II)-Morin complex gives dehydration and decomposition patterns. The TG plot demonstrated the decomposition in four main steps as provided in Table 6 . The net weight loss of about $88.28 \%$ in decomposition steps occurred between the range of $56-524{ }^{\circ} \mathrm{C}$. The first decomposition step, observed within the temperature range $56-120{ }^{\circ} \mathrm{C}$, with an estimated mass loss of $11.03 \%$ (Calc. mass $=53.73 \mathrm{~g}$ ) may be attributed to the liberation of three moles of hydrated water molecules. The second decomposition was observed at 121-184 ${ }^{\circ} \mathrm{C}$, corresponding to $7.89 \%$ (calc. mass $36.2 \mathrm{~g}$ ) weight loss, coincides with the two coordinated water molecules. Hence, it was observed that complex comprises of three crystalline and two coordinated water molecules as supported by IR and DSC studies (Figs. 7 (complex spectrum) and 8). IR spectrum of the complex also shows the presence of water of crystallization by appearance of broad band for $\mathrm{v}(\mathrm{O}-\mathrm{H})$ at $3389 \mathrm{~cm}^{-1}$. DSC curve in Fig. 8 gives the characteristic thermal events with $20{ }^{\circ} \mathrm{C}$ $\mathrm{min}^{-1}$ heating rate showing endothermic and exothermic peaks which are in agreement with weight losses given by TG.
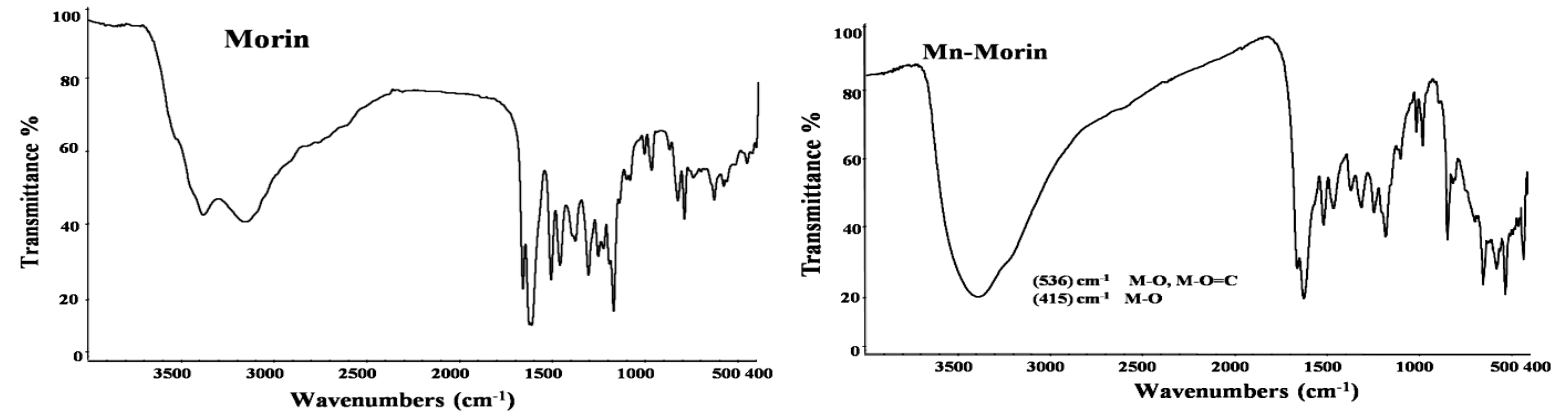

Figure 7. FT-IR spectra of morin and Mn(II)-Morin complex

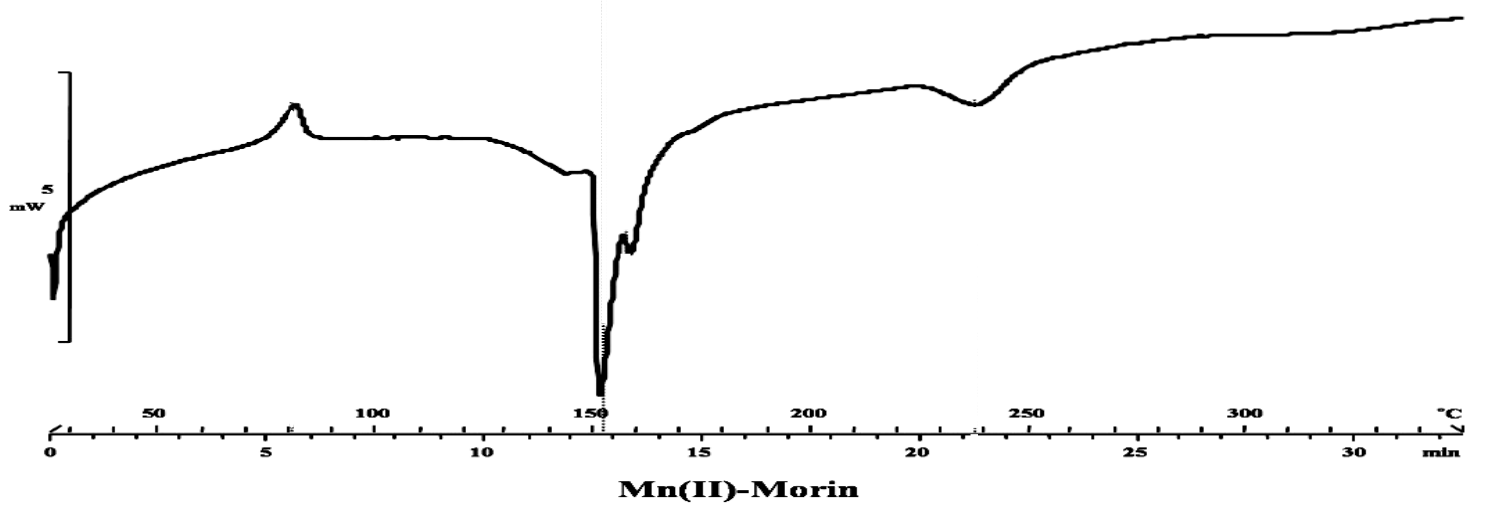

Figure 8. DSC curve for Mn(II)-Morin complex

Table 6. Thermogravimetric analysis destruction patterns of Mn(II)-Morin complex.

\begin{tabular}{|c|c|c|c|c|c|}
\hline \multirow[t]{2}{*}{ Complex } & \multirow[t]{2}{*}{ Molecular wt g/mol } & \multirow{2}{*}{$\begin{array}{c}\text { Decomposition } \\
\text { Temperature }\left({ }^{\circ} \mathrm{C}\right)\end{array}$} & \multirow[t]{2}{*}{ Eliminated Species } & \multicolumn{2}{|c|}{ Mass Loss (\%) } \\
\hline & & & & Found & Calculated \\
\hline \multirow{6}{*}{ 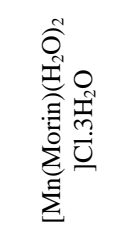 } & \multirow{6}{*}{ 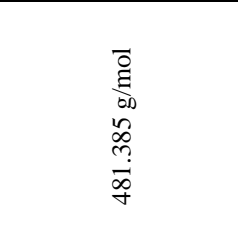 } & $56-120$ & $3 \mathrm{H}_{2} \mathrm{O}$ & 11.03 & 11.22 \\
\hline & & $121-184$ & $2 \mathrm{H}_{2} \mathrm{O}$ & 7.89 & 7.48 \\
\hline & & $185-324$ & $\mathrm{C}_{6} \mathrm{H}_{5} \mathrm{O}_{2}$ & 21.97 & 22.64 \\
\hline & & $325-524$ & $\mathrm{C}_{9} \mathrm{H}_{4} \mathrm{O}_{5}+\mathrm{Cl}$ & 47.39 & 47.24 \\
\hline & & Total loss & & 88.28 & 88.58 \\
\hline & & Solid Residue & $\mathrm{Mn}$ & 10.64 & 11.41 \\
\hline
\end{tabular}


DSC curve also provides useful information regarding the complex structure. It shows an endothermic peak at $80{ }^{\circ} \mathrm{C}$ for the dehydration of the complex. In addition, the thermal event sighted at $152{ }^{\circ} \mathrm{C}$ shows the complex melting point. The exothermic thermal peaks at $158{ }^{\circ} \mathrm{C}, 239{ }^{\circ} \mathrm{C}$ and above may correspond to the degradation of remaining organic matter of the complex. The Mn metal remains as final residue because metal oxides are not acquired under nitrogen atmosphere [33]. Thus, the complex structure can be proposed as Fig. 9 from decomposition data presented in Table 6.

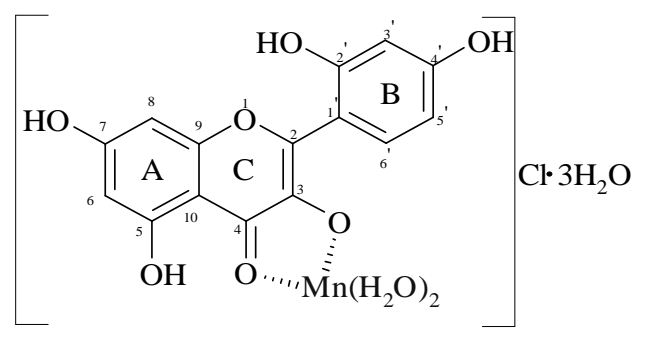

Figure 9. Proposed structure of Mn(II)-Morin complex

\section{Structure of the complex}

Mn(II) shows $d^{5}$ electronic configuration which has no any crystal field stabilization energy (CFSE) specific to any particular geometry. Hence, for $\mathrm{Mn}(\mathrm{II})$ complexes, different geometries are actually expected. Moreover, it's very surprising that most of the $\mathrm{Mn}(\mathrm{II})$ complexes exhibit octahedral while just few ones display other types of coordination geometries [34,35]. In addition, the current study also describes the octahedral geometry of the complex as supported by spectral and thermal studies.

\section{Antioxidant activity of morin and the complex by DPPH radical scavenging method}

The antioxidant activity of pure morin and its $\mathrm{Mn}$ (II) complex was measured by UV-visible spectroscopy. The measurement is done on the basis of electron and hydrogen donating/radical scavenging activities. Morin and DPPH react in two steps where in one step quick decay in absorbance of DPPH occurs at $515 \mathrm{~nm} \lambda_{\max }$, (where the reaction occurs within 60-120 seconds in methanol); while second step corresponds to very slow decay around $1 \mathrm{~h}$ to give a constant value. In quick step, most labile $\mathrm{H}$-atom is abstracted from morin to DPPH, whereas in slow step remaining activity in oxidation degradation product is measured.

It has been early explored that antioxidant activity of flavonoids depends upon their molecular structures. Fig. 10 demonstrates the relative DPPH scavenging activity of pure morin and its $\mathrm{Mn}$ (II) complex. Thus, from the graph it can be inferred that the complex exhibits higher antioxidant activity than pure morin and subsequently indicates that metal ion $(\mathrm{Mn}[\mathrm{II}])$ shows the significant change in the chemical properties of whole ligand molecule [31].

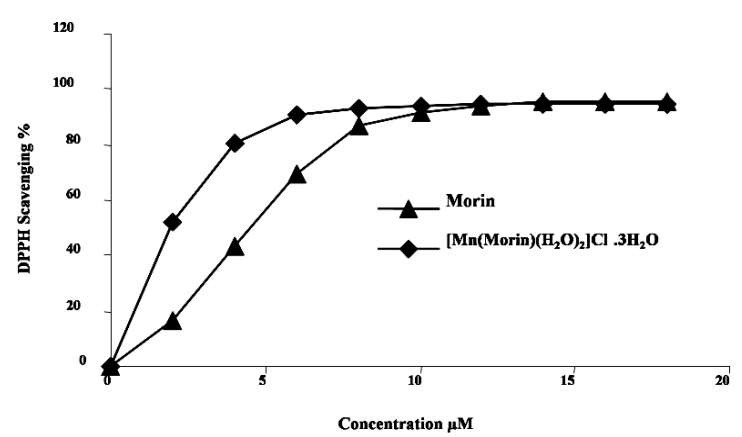

Figure 10. Relative antioxidant activity of morin and $\mathrm{Mn}$ (II)Morin complex

\section{Antimicrobial activity}

The antibacterial activity of morin and corresponding $\mathrm{Mn}$ complex was relatively explored against two bacterial pathogenic species. In Table 7, the data about antibacterial screening has been presented. It has been observed that the metal complex has shown an increase in the inhibition zones relative to the corresponding ligand, which indicates the decreased bacterial population caused by the metal complex. Thus, the study suggests that the metal complex is more antibacterial than the free ligand molecule. This increased antibacterial activity of the complex can be explained on the basis of metal's oxidation state, overtone concept and Tweedy's chelation theory [36]. Thus, the enhanced antibacterial activity of the complex is due to its increased lipophilic character. It is found that the cellular enzymes play very important role in the different metabolic pathways of microorganisms but the complex affects these cellular enzymes and cause their deactivation. 
Table 7. Antimicrobial activity of morin and its Mn(II) complex.

\begin{tabular}{|c|c|c|c|c|c|c|c|c|c|c|c|c|}
\hline \multirow{3}{*}{$\begin{array}{l}\text { Compounds } \\
\text { Concentrations }\end{array}$} & \multicolumn{11}{|c|}{ Diameter of inhibition zone of bacteria by ligand and complex (mm) } & \multirow[b]{3}{*}{$0.3 \%$} \\
\hline & \multicolumn{5}{|c|}{ Proteus vulgaris (-ve) } & \multicolumn{6}{|c|}{ Staphylococcus aureus (+ve) } & \\
\hline & $0.05 \%$ & $0.1 \%$ & $0.15 \%$ & $0.2 \%$ & $0.25 \%$ & $0.3 \%$ & $0.05 \%$ & $0.1 \%$ & $0.15 \%$ & $0.2 \%$ & $0.25 \%$ & \\
\hline Morin & 1.1 & 2.0 & 2.9 & 4.7 & 6.3 & 7.5 & 1.3 & 2.2 & 3.5 & 4.2 & 7.3 & 8.4 \\
\hline Mn(II)-Morin & 1.6 & 2.7 & 5.3 & 7.6 & 8.3 & 9.5 & 1.9 & 3.6 & 6.2 & 8.1 & 9.7 & 10.5 \\
\hline Ciprofloxacin & 8.6 & 13.3 & 17.4 & 20.7 & 23.2 & 25.6 & - & - & - & - & - & - \\
\hline Streptomycin & - & - & - & - & - & - & 9.7 & 15.3 & 19.5 & 22.7 & 25.1 & 27.8 \\
\hline DMSO & +ve & +ve & +ve & $+\mathrm{ve}$ & $+\mathrm{ve}$ & $+\mathrm{ve}$ & +ve & +ve & $+\mathrm{ve}$ & $+\mathrm{ve}$ & $+\mathrm{ve}$ & $+\mathrm{ve}$ \\
\hline
\end{tabular}

In this way, these toxicants show ultimate action and denature the one or more proteins resulting in impairing the normal cellular processes. The complex thus inhibits the microorganism growth because enzymes are highly affected and hence microorganisms become unable to use their food or there is decreased nutrient intake in proper form whereas the growth of microorganisms is completely arrested, while high concentrations are fatal [37].

\section{Conclusion}

The study concludes regarding the complex formation between $\mathrm{Mn}$ (II) metal ion and morin flavonoid molecule. The complex was synthesized and characterized based on the spectral and analytical data and formulated as $\left[\mathrm{Mn}\left(\right.\right.$ Morin) $\left.\left(\mathrm{H}_{2} \mathrm{O}\right)_{2}\right] \mathrm{Cl}_{3} 3 \mathrm{H}_{2} \mathrm{O}$. The electronic spectroscopic data demonstrated that the morin exhibits the two main bands at 357 and $262 \mathrm{~nm}$, but the absorption bands were shifted to longer wavelength maximum $\left(\lambda_{\max }\right)$ with appearance of new bands at 420 and $267 \mathrm{~nm}$ in case of complex formation. The interaction was validated with Job's plot for stoichiometric composition of complex that was found to occur at 1:1 (L/M). Ultimately, all the data is in accordance with that the $3-\mathrm{OH}$ moiety is an active coordination site to be involved in complexation jointly with carbonyl function moiety as verified by FT-IR spectroscopy. For antioxidant activity, flavonoids are recognized to depend on the positions and number of $\mathrm{OH}$ groups. While the $\left[\mathrm{Mn}(\right.$ Morin $\left.)\left(\mathrm{H}_{2} \mathrm{O}\right)_{2}\right] \mathrm{Cl}_{3} 3 \mathrm{H}_{2} \mathrm{O}$ is explored currently to show the increased antioxidant as well as antimicrobial activities relative to pure morin. Thus, it could be suggested that the chemical properties of the morin are significantly changed with the metal ion (Mn[II]) compliant with chelation law. Hence, it signifies that the ligand molecule may act as antidote or chelating ligand to medically treat the metals overload or poisoning. Thus, the flavonoids being vital source of nutrition were ignored as antioxidants due to their low efficiency; this problem has now been overcome by complexing the flavonoids with metal ions resulting in formation of complexes with enhanced antioxidant/antimicrobial properties.

\section{Acknowledgement}

The authors highly acknowledge the National center of Excellence in Analytical Chemistry, University of Sindh, Jamshoro, which supported this whole work.

\section{References}

1. P. G. Pietta and J. Nat. Prod., 63 (2000) 1035. doi.org/10.1021/np9904509

2. S. A. Farhan, Int. J. Chem. Sci., 11 (2013) 1247.

3. S. Selvaraj, S. Krishnaswamy, V. Devashya, S. Sethuraman and U. M. Krishnan, Med. Res. Rev., 34 (2014) 677.doi.org/10.1002/med.21301

4. R. F. V. De Souza, E. M. Sussuchi and W. F. De Giovani, Synth. React. Org. Met. Org. Chem., 33 (2003)

1125.doi.org/10.1081/SIM-120023482

5. S. Kumar and A. K. Pandey, The Scientific World Journal, 2013, Article ID 162750, 16 pages, 2013.doi:10.1155/2013/162750

6. G. Forkmann and S. Martens, Curr. opin. Biotechnol., 12 (2001) 155. doi.org/10.1016/S0958-1669(00)00192-0 
7. V. A. Kostyuk, A. I. Potapovich, E. N. Vladykovskaya, L. G. Korkina and I. B. Afanas'ev, Arch. Biochem. Biophys., 385 (2001) 129. doi.org/10.1006/abbi.2000.2118

8. Y. Liu and M. Guo, Molecules, 20 (2015) 8583. doi.org/10.3390/molecules20058583

9. Y. Liu, X. He, H. Zuo, Q. Zhang, Z. Li and L. Shi, Zhongguo Zhong Yao Za Zhi, 37 (2012) 1901.

10. R. F. V. de Souza and W. F. De Giovani, Redox Rep., 9 (2004).

11. D. X. West, A. E. Liberta and S. B. Padhye, et al., Coord. Chem. Rev., 123 (1993) 49. doi.org/10.1016/0010-8545(93)85052-6

12. R. A. Sanchez-Delgado, K. Lazardi and L. Rincon, et al., J. Med. Chem., 36 (1993) 2041.doi.org/10.1021/jm00066a014

13. M. A. Elsome, J. M. T. Hamilton-Miller and W. Brmfitt, et al., J. Antimicrob. Chemother., 37 (1996) 911.doi.org/10.1093/jac/37.5.911

14. G. N. Ramesha, Y. S. Raoc, B. Prathimaa, V. Sravanid and A. V. Reddya, Pharm. Lett., 4 (2012) 1299.

15. R. Elayaperumal and P. Dharmalingam, Inter. J. Chem. Anal. Sci., 3 (2012) 1391.

16. G. Nadaska, J. Lesny and I. Michalik, HEJ: ENV-100702-A, J. Herdu, Trnava, SK-917 01, Slovakia, page, 1.

17. J. Emsley. "Manganese". Nature's Building Blocks: An A-Z Guide to the Elements. Oxford, UK: Oxford University Press. (2001).

18. D. S. Avila, R. L. Puntel and M. Aschner. "Chapter 7. Manganese in Health and Disease". In Astrid Sigel, Helmut Sigel and Roland K. O. Sigel. Interrelations between Essential Metal Ions and Human Diseases. Metal Ions in Life Sciences 13 (2013) 199. doi.org/10.1007/978-94-007-7500-8_7

19. T. Brody, Nutritional Biochemistry. San Diego: Academic Press, (1998).

20. American Society for Nutritional Sciences (ASNS). 9650 Rockville Pike, Suite 4500, Bethesda, MD 20814. (301) 634-7050. Web site: http://www.nutrition.org.

21. A. Takeda, Brain Res. Rev., 41 (2003) 79. doi.org/10.1016/S0165-0173(02)00234-5
22. E. Chalmin, M. Menu and C. Vignaud, Meas. Sci. Technol., 14 (2003) 1590. doi.org/10.1088/0957-0233/14/9/310

23. N. Law, M. Caudle and V. Pecoraro, $A d v$. Inorg. Chem., 46 (1998) 305.

24. IOM. Institute of Medicine. Dietary reference intakes: Vitamin A, vitamin K, arsenic, boron, chromium, copper, iodine, iron, manganese, molybdenum, nickel, silicon, vanadium, and zinc. Washington DC: National Academy Press; 2001.

25. A. B. Santamaria, Indian J. Med. Res., 128 (2008) 484.

26. H. D. Revanasiddappa, L. Shivakumar, K. S. Prasad, B. Vijay and B. Jayalakshmi, Chem. Sci. J., 2012 (2012) 9, CSJ-64.

27. D. C. Harris, Quantitative Chemical Analysis, third ed., W. H. Freeman and Company, New York, (1991).

28. Q. K. Panhwar and S. Memon, J. Coord. Chem., 64 (2011) 2117. doi.org/10.1080/00958972.2011.590192

29. W. Brand-Williams, M. E. Cuvelier and C. Berset, Food Sci. Technol., 28 (1995) 25.

30. S. B. Bukhari, S. Memon, M. M. Tahir and M. I. Bhanger, Spectrochim. Acta A, 71 (2009) 1901. doi.org/10.1016/j.saa.2008.07.030

31. Q. K. Panhwar, S. Memon and M. I. Bhanger, J. Mol. Struct., 967 (2010) 47. doi.org/10.1016/j.molstruc.2009.12.037

32. S. B. Bukhari, S. Memon, M. M. Tahir and M. I. Bhanger, J. Mol. Struct., 892 (2008) 39. doi.org/10.1016/j.molstruc.2008.04.050

33. Q. K. Panhwar and S. Memon, Chem. Pap., 68 (2014) 614. doi.org/10.2478/s11696-013-0494-6

34. F. A. Cotton and G. Wilkinson, Advanced Inorganic chemistry, Wiley Interscience, (1988).

35. M. Mikuriya,Y. Hatano and E. Asato, Bull. Chem. Soc. Jpn., 70 (1997) 2495.doi.org/10.1246/bcsj.70.2495

36. Q. K. Panhwar and S. Memon, J. Mod. Med. Chem., 2 (2014) 1.

37. A. C. Tella and J. A. Obaleye, Orbital: Electron. J. Chem., 2 (2010) 11. 